\title{
Komunikace úřadů s občany, E-government
}

\section{Vanda Šimánková}

Vedoucí práce: doc. JUDr. Pavel Mates, CSc.

\section{1. Úvod}

Každý občan přichází ve svém běžném životě do styku s orgány státní správy. Záležitostí kvůli nimž musí občan komunikovat s úřady existuje celá řada a na různých úrovních veřejné správy. V současné době, kdy je životní tempo výrazně rychlejší než v minulosti a lidé jsou velmi zaneprázdněni, zejména prací, kariérou a svojí rodinou, stále častěji volí jiné alternativy, jak si spolupráci s úřadem ulehčit.

V posledních letech se stále více rozšiřují informační technologie mezi domácnosti. Myslím, že je zajímavé shrnout, co všechno dnes umožňuje počítačová gramotnost a informační technologie jako celek.

Ve své seminární práci se chci zaměřit na různé způsoby komunikace mezi úr̆ady a občany. Zda dávají přednost klasickému vyřizování úředních záležitostí a v jaké míře upřednostňují nové moderní technologie. Dále se budu věnovat termínu E-government, co vše nabízí a na jaké úrovni je dnes v České republice. V další části bych chtěla nastínit jak taková komunikace funguje $\mathrm{v}$ praxi, prostřednictvím webových stránek konkrétního úřadu městské části, a to Úřadu městské části Prahy 6. Nejen pro osobní vztah k této části Prahy, ale také proto, že získala 1. místo v krajském kole o nejlepší webové stránky v roce 2006 a které toho mohou skutečně mnoho nabídnout.

\section{Komunikace mezi obecními úřady a občany}

Jednou ze základní činností obecních úřadů je komunikace s občany, je to činnost velmi důležitá a neopomenutelná. Obecní úřady mohou komunikovat s občany mnoha způsoby a využívají k tomu celou řadu prostředků, jako je např. místní tisk, místní rozhlas, vlastní periodikum, internet, krátké textové zprávy pomocí mobilních telefonů, ale i tradiční způsoby komunikace, jako jsou úřední desky, vývěsky, letáčky či besedy s občany. Škála takové komunikace je opravdu pestrá a nabízí občanům různé možnosti styku s úřady a jejich informacemi.

Z průzkumů na téma komunikace úřadů s občany vyplývá, že téměř všechny obecní úřady využívají místní tisk. Rozšiřuje se i místní televizní vysílání, ale spíše ve větších obcích, kde je využiván občany až ze dvou třetin. Naopak menší obce, a to přibližně tři čtvrtiny stále musí spoléhat na místní rozhlas, prostřednictvím kterého informují občany o novinkách, akcích, změnách apod. Celkem nová forma komunikace je realizována pomocí zasílání krátkých textových zpráv. V současné době se teprve rozvíjí a tedy není ještě moc rozšířená. Lze však očekávat postupné rozšiřování této komunikace, nebo v podstatě každý občan ČR vlastní mobilní telefon, což vyplývá ze statistik provozovatelů mobilních sítí na území ČR. Všechny obecní úruady musí nadále využívat tradiční prostředky komunikace, jako jsou informační tabule a úřední desky. Informační tabule a desky jsou zpravidla 
umís ovány na budově obecního úřadu anebo v jeho blízkosti na veřejném místě, aby mohli občané získat základní informace $\mathrm{v}$ jakoukoliv denní dobu. Velmi důležitou komunikací jsou pravidelné besedy s občany, jsou ale spíše využívány v největších obcích. Taková komunikace je velmi důležitá, nebo zde vzniká důležitý osobní kontakt mezi pracovníky úřadu a občany. Nejen že se občané seznámí s některými pracovníky úřadu osobně, ale mohou zde př́mo konfrontovat problémy, žádosti, doporučení a nesouhlasná stanoviska. Jak již bylo poznamenáno v úvodu, lidé dneska mají méně času, mnohokrát se ani nestačí zajímat o své okolí. Na obecní úřad dochází pouze z určité povinnosti a nutnosti. Z tohoto důvodu jsou pravidelné besedy méně využívány. $\mathrm{K}$ dalším prostředků, které jsou využívané ke komunikaci s občany jsou např. ankety a dotazníkové akce, v odůvodněných př́padech letáčky do všech domácností, dále veřejné jednání zastupitelstev, vývěsky v obchodech, vlastní periodika, různé elektronické infokanály, tiskové konference či veřejná projednávání.

Ke komunikaci se v dnešní době hojně využívá internet, a to ve obcích nad 20000 obyvatel, ale i ty menší využívají internet ke komunikaci s občany z více než $85 \%$. Internet je současní dnešního života, stává se standardním prostředkem komunikace nejen mezi obecními úřadu a občany, ale celé společnosti. Internet domů si pořizuje stále více domácností, nebo v současné době je pořízení i provoz internetu relativně levnou záležitostí. Vlastní internetové stránky mají v podstatě všechny obecní úřady, které touto formou zpř́stupňují důležité informace všem občanům, a to po dobu 24 hodin denně.

Míra využití jednotlivých prostředků komunikace úřadu s občany (v \%).

Tab. ̌̌. 1

\begin{tabular}{||l|c|c|c||}
\hline \multirow{2}{*}{ Prostředek komunikace } & \multicolumn{3}{|c||}{ Velikost obce } \\
\cline { 2 - 4 } & \multirow{2}{*}{ Do 4 999 obyv. } & $\begin{array}{c}\text { Od 5 000 do } \\
\mathbf{1 9 9 9 9} \text { obyv. }\end{array}$ & \multirow{2}{*}{ Nad 20 000 obyv. } \\
\hline Místní tisk & 94,7 & 97,7 & 100,0 \\
\hline Místní televizní vysílání & 20,2 & 31,0 & 66,7 \\
\hline Místní rozhlas & 74,5 & 51,7 & 43,3 \\
\hline Internet & 86,2 & 93,1 & 100,0 \\
\hline Zasílání SMS & 12,8 & 16,1 & 16,7 \\
\hline Informační tabule & 84,0 & 88,5 & 83,3 \\
\hline Úřední desky & 95,7 & 100,0 & 100,0 \\
\hline Pravidelné besedy s občany & 36,2 & 41,4 & 66,7 \\
\hline
\end{tabular}

Zdroj: Veřejná správa, 2006, č. 49.

Z uvedené tabulky vyplývá, že nejrozšířenějším komunikačním prostředkem jsou úřední desky, poté místní tisk a internet. Naopak nejméně používaným prostředkem je zasílání krátkých textových zpráv a místní televizní vysílání.

\section{E-government}

Výraz e-government se stal již součástí moderní mluvy, proto se snad ani nehledá odpovídající český překlad. Co všechno zahrnuje pojem E-government? Jedná se vesměs 
o různé úkoly zabývající se elektronizací výkonu činnosti veřejné správy.Jeho hlavním smyslem a funkcí je poskytnout lidem větší komfort při jednání se státem a jeho orgány. To se podaří, jestliže se zjednoduší a urychlí komunikace občanů a podnikatelských subjektů s těmito orgány. Nejedná se pouze o výhodu pro adresáty, ale také pro úředníky, kteří se méně musí věnovat papírům. Platí to jak v prŕípadě, že dotyčný od úřadu něco chce, tak i v prřípadě že se stává účastníkem řízení z iniciativy př́islušného orgánu.

Důsledkem dobře fungujícího E-governmentu by mělo být pronikavé zefektivnění výkonu veřejné moci jak z hlediska účastníků, tak i z hlediska státu jako takového. ${ }^{1}$ Významnou výhodou e-governmetu jsou jistě úspory času i peněz. Jak bylo zmíněno v úvodu, lidé jsou v současné době velmi zaneprázdněni. Jsem si proto jistá že ocení možnost nemuset trávit čas dojížděním a čekáním na úřadech, ale naopak získat informaci nebo stáhnout si formuláŕ přímo ze svého bydliště nebo kanceláře a po vyplnění ji zase odeslat.

Výrazně se tímto také zjednodušuje komunikace uvnitř státního aparátu, jak na úrovni vertikální i horizontální, dochází také k úspoře prostředků /odpadají náklady na poštovné, papír a prostory pro archivování/ a personálu. Další předností e-governmentu je rychlost a kontinuita úráadování. Jednoduché záležitosti lze vyřídit doslova kliknutím na klávesnici počítače, zároveň se zrychlí i vybavení věcí složitějších. Tím že může úředník snadno a rychle vyhledávat $\mathrm{v}$ uspořádaných databázích a odpadají prodlevy spojené s doručováním listinných dokumentů. To všechno umožňuje, že úřady mohou fungovat 7 dní v týdnu 24 hodin denně. Výhodou je také rozšíření rozpětí řízení, protože díky komunikačním prostředkům bude možno data, údaje a informace mezi jednotlivými stupni veřejné správy předávat, aniž by bylo potřeba dalších mezistupňu. ${ }^{2}$

$\mathrm{K}$ vytvoření takového dobře fungujícího systému jsou samozřejmě nutné nemalé vstupní investice, které se však relativně brzy vrátí. Přičemž efekt, který přinesou je s penězi nesrovnatelný.

E-government je také významným nástrojem k zajiš ování transparentnosti ve veřejné správě. Občané mají snazší přístup k informacím a tak mohou lépe kontrolovat činnost orgánů veřejné moci /prostřednictvím elektronických médií mohou lidé napřr. sledovat zasedání zastupitelských orgánů na ústřední i lokální úrovni nebo se vyjadřovat $\mathrm{k}$ veřejným záležitostem pomocí diskusních fór apod./. Odpadá tedy nutnost bezprostředního kontaktu občanů s úředníky, a tím tedy i potenciální nebezpečí např. korupce /pravděpodobně nikdo nebude riskovat žádat nebo nabízet úplatek prostřednictvím emailu/. E-government přispívá k tomu, co je označováno jako „dobrá správa“. Pomáhá k odklonu od vrchnostenského pojetí správy. Veřejná správa se stává službou občanům, jakožto zákazníkům.

Základním předpokladem pro fungování e-governmentu je dostupnost internetu a schopnost s ním pracovat. Tento problém a jeho řešení je považováno za jednu z priorit státní informační a komunikační politiky, jejímž cílem je zajistit dostupné a bezpečné komunikační služby. K realizaci e-governmentu je nutné vybudování potřebné infrastruktury a proškolení úředníků v jejím využívání.

Česká republika tuto otázku již vyřešila. Podle studie časopisu The Economist ze srpna 2004 byla ČR na druhém místě ve kvalitě rozvoje elektronické veřejné správy v rámci skupiny nových členských států EU a v některých parametrech předstihla i původní členské státy unie ${ }^{3}$.

K 31.12.2005 byly připojeny $\mathrm{k}$ internetu všechny organizační složky státu, kraje a obce s více jak 500 obyvateli a přes $90 \%$ obcí s méně než 500 obyvateli. Co se týče vyso-

1 MATES, P. - SMEJKAL, V. E-government v českém právu. 1. vyd. Praha: Linde, 2006, s. 9.

2 Srov. MATES, P. - SMEJKAL, V. E-government v českém právu. 1. vyd. Praha: Linde, 2006, s. 10.

3 Srov. MATES, P. - SMEJKAL, V. E-government v českém právu. 1. vyd. Praha: Linde, 2006, s. 18. 
korychlostního připojení Internetu v ČR v mezinárodním srovnání, tak ČR se umístila /v počtu vysokorychlostních př́pojek na 100 obyvatel/ s počtem 6,4 těsně za Irskem, před Řeckem, Mad'arskem, Polskem i SR v zemích OECD. ${ }^{4}$

Dosud jsme ovšem hovořili o otázce vybavenosti výpočetní technikou na straně úřadů. Je však nutné shrnout také jaké možnosti využití výpočetní techniky jsou na straně adresátů. V porovnání s vybavením státních orgánů výpočetní technikou jsou na tom domácnosti u nás výrazně hưr̆e.

$\mathrm{V}$ polovině roku 2006 mělo doma $\mathrm{k}$ dispozici osobní počítač $36 \%$ tedy asi 1,5 milionu domácností, 27\% /1,12 mil./domácností má připojení k internetu a pouze $15 \%$ domácností má vysokorychlostní připojení. ${ }^{5}$

Tím vzniká handicap, o jehož vyrovnání usilují různé projekty. Cílem těchto projektů je vytvořit pro všechny občany předpoklady $\mathrm{k}$ tomu, aby mohli tyto technologie využívat. V projektech se jedná o taková opatření jako jsou např. vytvoření možností používání Internetu občany $\mathrm{v}$ prostorách úřadoven, bezplatné připojení na internet $\mathrm{v}$ některých městech nebo jejich částech /př́ikladem tohoto opatření se budu zabývat ještě v další části mé práce viz kap. 5./, nebo také koncepční strategie např. Státní informační a komunikační politika e-Česko 2006, program Národní politika pro vysokorychlostní internet či plán EU označený jako eEurope.

Přese všechny snahy u nás se zatím občané chovají rezervovaně k možnostem, které e-government nabízí, zvláště ke vztahu ke státní orgánům. V České republice používá on-line služeb v úřadech pouze $18 \%$ populace, zatímco ve Skandinávských zemích je to přes $50 \%{ }^{6}$ Tuto situaci by mohly zlepšit projekty na rozvoj počítačové gramotnosti. Ty jsou zaměřeny hlavně na starší obyvatelstvo a venkovské obce, kde je využívání výpočetní techniky výrazně menší než u mladších lidí a ve městech

Pro úspěšné zavedení e-governmentu je rovněž nutné vytvořit určité právní prostř̌edí prostřednictvím právního předpisu. To je však vzhledem ke složitým technickým a organizačním záležitostem náročné. K tomu aby mohl být e-government úspěšně zaveden a realizován je však minimálně nutné uzákonění nástrojů $\mathrm{k}$ rychlému a bezpečnému předávání prostřednictvím výpočetní techniky /zákon o elektronickém podpisu/, dále vymezit úkoly veřejné správy při správě informačních systémů /zákon o informačních systémech veřejné správy/, ale také napřx. úprava ochrany osobních údajů.

\section{Využívání internetu ve vztahu k veřejné správě - jednotlivci}

Internet ve vztahu $\mathrm{k}$ veřejné správě použilo $\mathrm{v}$ posledních 12 měsících (sběr dat v 2.čtvrtletí 2006) celkem 16,7\% uživatelů internetu. Největší podíl jednotlivců, kteří použili internet ve vztahu k veřejné správě, je mezi uživateli internetu s vysokoškolským vzděláním (47,2\%), naopak nejmenší mezi uživateli se základním vzděláním $(5,8 \%)$ a mezi jednotlivci ve věku 65 let a více $(2,8 \%)$.

4 Šetření ČSU o využívání informačních a komunikačních technologií v roce 2005.

5 Výsledky šetření ČSÚ o využívání ICT v domácnostech a mezi jednotlivci v roce 2006.

6 MATES, P. - SMEJKAL, V. E-government v českém právu. 1. vyd. Praha: Linde, 2006, s. 21. 


\section{Graf č. 1}

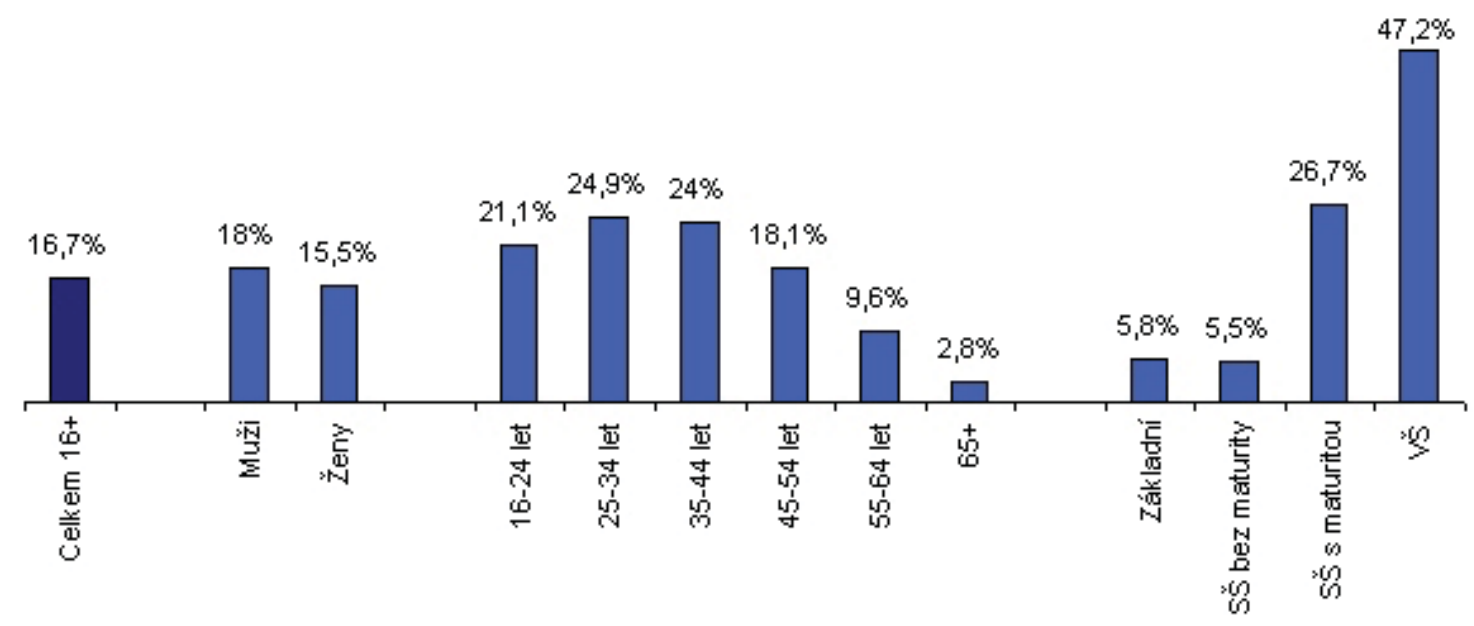

zdroj: ČSÚ. [online]. URL: <http://www.czso.cz/csu/redakce.nsf/i/verejna_sprava.cz >

\section{Komunikace občanů Prahy $6 \mathrm{~s}$ městským úřadem}

\subsection{Základní informační zdroje Úřadu městské části}

Mezi základní informační zdroje patří úřední deska městské části, webové stránky a dále tištěná i internetová podoba měsíčníku Šestka.

\subsection{1 Úřední deska}

Úřední deska městské části existuje jak v hmotné podobě, tedy je př́mo umístěna na Úřadě městské části Prahy 6 , tak i v elektronické podobě, ta je umístěna na webových stránkách úřadu. Jejím cílem je podávat informace obyvatelům městské části z jednotlivých odborů.

Obr. č. 1: Úřední deska v elektronické podobě

\section{Úřední deska}

aktuálni zprávy • archivní zprávy

(0)

Doručení písemnosti veřejnou vyhláškou (43) Granty (3) Informace (8)

Konkurzni rizení na obsazení funkce (1)

Nezar̉azeno (25)

Odpady, kontejnery, sbèrné dvory (8) Oznámení (3)

Prodej bytů - výbèrové ǐizení (1)

Pronájem byti̊ - výbèrové rízení (4)

Pronájem nebytových prostor - výběrové îizeni (2) Veřejné vyhlášky (18) Volby (4)

Volná pracovní místa na ÚMČ Praha 6 (5)

Výbèrové řizení na prodej nemovitosti (2) Výstavba (1)

všechny oblasti

Zdroj: [online]. URL: <http://www.praha6.cz/tabule/index.php $>$
Na úřední desce jsou vyvěšeny nově vydané vyhlášky, aby se s nimi mohli obyvatelé seznámit. Dále informace o výsledcích zasedání zastupitelstva, konkurzních řízeních na obsazení funkcí, o pronájmu a prodeji bytů, nebytových prostor a pozemků, o volných pracovních místech apod. Taktéž zde nalezneme např́klad informace o prrerušení dodávky elektřiny, vody apod. $\mathrm{v}$ důsledku havárií nebo jiných důvodu.

Výhodou internetové podoby úřední desky je, že jde celkem snadno dohledat i starší informace, nebo na webových stránkách existuje také archiv dokumentů, které byly v minulosti na úřední desce vyvěšeny.

V dnešní době, kdy je vysoké procento počítačové gramotnosti, zvláště v Praze, je nejjednodušší hledat infor- 
mace na webových stránkách. Je otázkou zda tu nechybí onen osobní kontakt. Nicméně co se týče informací, které bývají vyvěšovány na úřední desce a zároveň na webových stránkách, tak pro ty co disponují internetovým připojením jsou takové informace velmi snadno dostupné.

\subsection{2 Časopis Šestka}

Obr. č. 2: Časopis

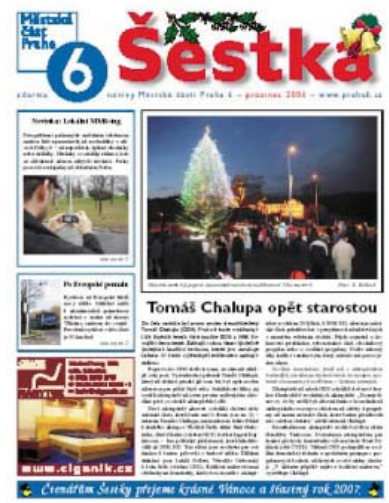

Tento časopis je pro obyvatele městské části Praha 6 vydáván měsíčně. Je distribuován prŕímo do schránek obyvatel. Od roku 2000 jej také nalezneme v internetové podobě na webových stránkách.

Zdroj: [online] URL:

http://www.sestka.cz/

\subsubsection{Webové stránky městské části}

Stránky městské části Prahy 6 zvítězily v roce 2006 v krajském kole o nejlepší webové stránky městských částí.

Webové stránky jsou přehledné a lze zde nalézt velké množství různorodých informací. Nalezneme zde základní informace o volených orgánech jako je zastupitelstvo, starosta, rada, výbory a komise, data jejich zasedání apod.

V sekci úřad se nachází již zmíněná internetová podoba úřední desky. Zajímavý je odkaz „Potřebuji vyř́ídit“, který obsahuje přehledné návody jak postupovat v př́ípadě podávání nejběžnějších žádostí, jako jsou žádosti o vystavení nového pasu nebo občanského průkazu, vydání duplikátu oddacího, rodného nebo úmrtního list, ohlášení drobné stavby nebo stavebních úprav, ohlášení živnosti, uzavření manželství, podání petice a mnoho dalších z různých odborů úřadu Prahy 6. U jednotlivých návodů je možné rovnou stáhnout a uložit odpovídající formuláře, které si může občan vyplnit a doma vytisknout. Dále se zde nacházejí informace o veřejných zakázkách.

Další sekce nazvaná Praha 6 nabízí svým obyvatelům tipy na výlety jak cyklistické, tak pěší, prostory pro strávení volnočasových, kulturních či sportovních aktivit. Obyvatelé zde naleznou obecné informace o Praze 6, o její historii i současnosti. Též statistická (např. sčítání lidu) a geografická data.

Sekce Informace obsahuje důležitá telefonní čísla a odkazy, různé organizace, které jsou zřizovány městskou částí jako jsou mateřské a základní školy nebo sociální a zdravotnická zařízení. Dále jsou zde zveřejněny adresy Úřadu městské části Prahy 6 a úřední hodiny, lze i vyhledávat pracovníky úřadu.

Velice zajímavou a užitečnou součástí těchto webových stránek jsou tzv. online služby, které se dělí dále na 7 částí:

1. část „Elektronické tržiště“ se městská část Praha 6 rozhodla využívat pro zadávání veřjejých zakázek menšího rozsahu. Elektronické tržiště by mělo umožnit rychlé získává- 
ní nabídek na realizaci zakázky, operativní rozhodování o výběru nejvhodnější nabídky a zároveň umožnit co nejširšímu okruhu uchazečů se o tyto méně rozsáhlé zakázky ucházet, aniž by jim vznikaly finanční náklady s registrací , se zpracováním nabídky atd.

2. část je novinka pod názvem „Lokální MMS-ing““. Jedná se o unikátní projekt v rámci České republiky. Tato část umožňuje upozorňovat na různé „nešvary“ a nedostatky na území městské části. Pro rychlejší nápravu a řešení by měla pomoci stále větší obliba a rozšířenost mobilních telefonů s fotoaparátem a také ochota občanů městské části se na řešení problémů spojených s úklidem a pořádkem podílet. Občané mohou pomocí zaslání multimediálních zpráv z mobilních telefonů upozornit na nějaký problém. Stačí odeslat fotografii $\mathrm{z}$ mobilního telefonu (př́ípadně i z počítače) např. rozbité lavičky, převrhnuté popelnice, rozbitého chodníku, neposekané trávy, pomalované „fasády“ nebo začínající skládky.

Co se týče této služby, zvedla se vlna diskuze o tom, zda tento způsob ohlašování nehraničí s udavačstvím. Proto také byla na stránkách Prahy 6 vytvořena anketa, aby se obyvatelstvo vyjádřilo, co si o této nové službě myslí. Z níže uvedené ankety vyplývá, že většina hlasujících souhlasí s touto službou, pokud nebude porušovat zákon na ochranu osobních údajů (údaje platné ke dni 16.12.2006).

Souhlasite se zasiláním MMS, zobrazujicich nešvary a problémy (nepořádek, špatné parkování apod.), na úřad a jejich následné zveřejňováni i s postupem řešení na webu?

1) Ano, je to rychlé a názorné. Stejně jsme všude natáčeni na různé průmyslové a bezpečnostni kamery, proto bych všechny přijaté MMS bez obav publikoval.

$32 \%$

2) Ano, je to originální způsob řešení místních problémů, publikované MMS však nesmí porušovat zákon na ochranu osobnich údajů.

$43 \%$

3) Ne, tento způsob jenom podporuje v lidech sklony $k$ udávání a snahu starat se o cizí záležitosti.

$25 \%$

Celkový počet hlasujicich: 302

3. část se týká „SMS news“. Tato služba umožňuje zasílání důležitých informací z radnice na zaregistrovaná čísla mobilních telefonů občanů formou krátkých textových zpráv (SMS). Služba funguje pro zákazníky všech tř́ českých mobilních operátorů. Zároveň se také formou SMS - anket lze vyjadřovat k otázkám, které se občanů bytostně dotýkají. Podle zájmu občanů se plánuje rozšíření služby o SMS - minireferenda, SMS - soutěže a členění zasílaných informací na různé tématické oblasti nebo vybírat př́ijemce zpráv např́íklad podle lokalit. Tato nová služba by měla zlepšit vzájemnou informovanost, a tím vést i ke zkvalitnění života $v$ městské části. Služba funguje tak, že odpovědný pracovník radnice může kdykoli z webové stránky u provozovatele služby napsat zprávu, která je automaticky rozeslána všem registrovaným občanům. V př́ípadě nouze lze zprávu odeslat všem registrovaným občanům prŕmo z mobilního telefonu. To může 
být užitečné především $\mathrm{v}$ krizových situacích, kdy může současně dojít $\mathrm{k}$ výpadku elektrické sítě, internetu, nebo je třeba odesílat zprávy př́imo z místa ohrožení.

4. část „Online rozhovory“ se zástupci úřadu městské části Prahy (např. se starostou) nebo s mediálně známými lidmi, jež mají hlubší vztah k Praze 6.

5. část „Zelená linka“ obsahuje kontakty na Úřad městské části Prahy 6

6. část „Elektronický úřad“" Zde nalezneme členění Úřadu městské části Prahy 6 , kontakty a působnosti jednotlivých odborů. Emailové adresy a telefonní čísla na jednotlivé pracovníky odborů.

Obr. č. 3: Elektronický úřad na webových stránkách

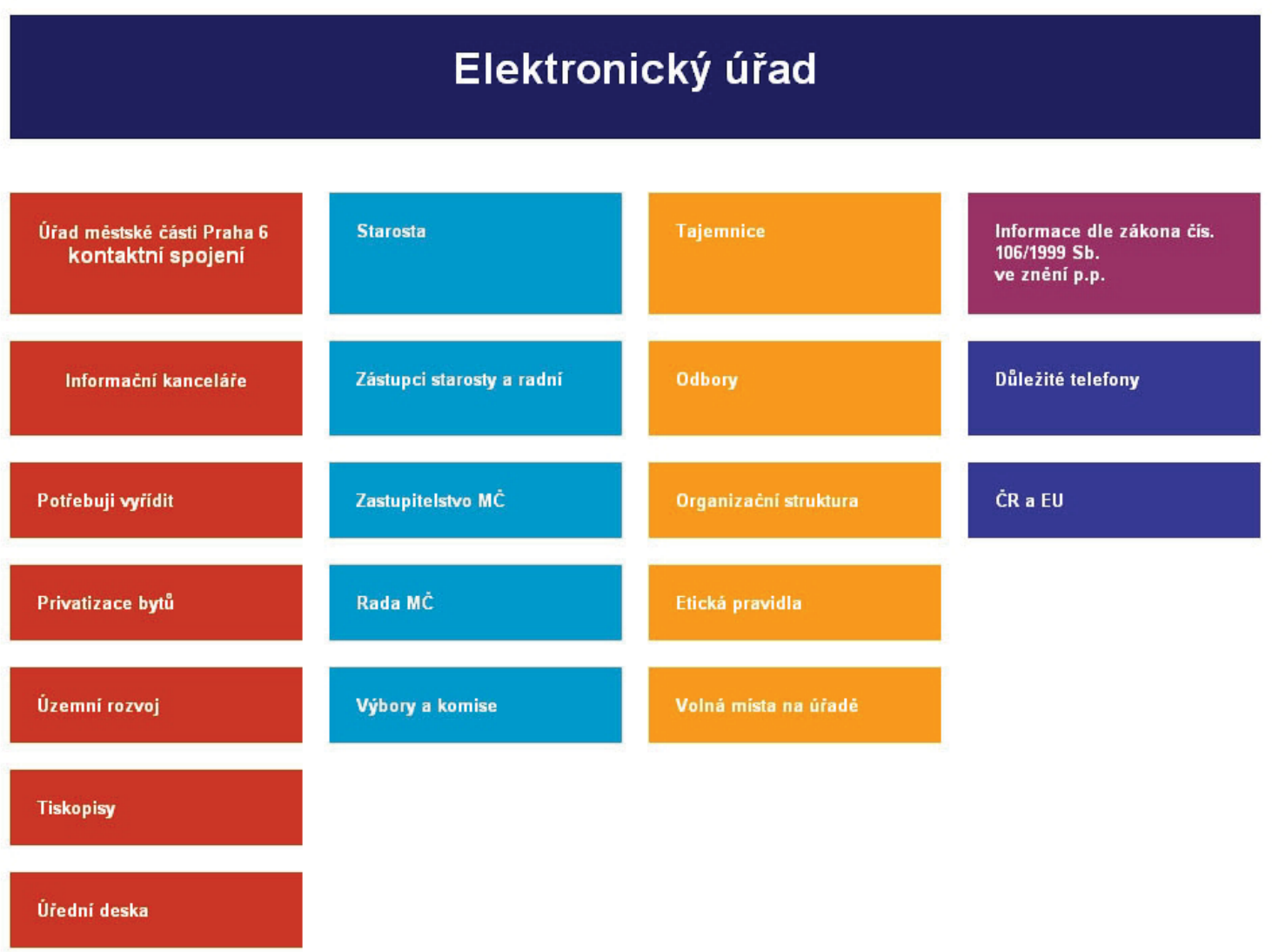

Zdroj: [online] URL: <http://www.praha6.cz/tabule/index.php>

7. část. "Novinky emailem". Díky této službě mohou občané získávat informace snadno do své emailové schránky. 


\section{Poskytování bezdrátového připojení $k$ internetu zdarma}

V této práci bych se chtěla ještě zmínit o městské části Praha 5, a to z důvodu, že zatím jako první v rámci celého města Prahy odstartovala projekt s poskytováním bezdrátového internetu zdarma.

Úřad městské části Prahy 5 se rozhodl přispět k budování informační společnosti svým podílem, tedy poskytnout občanům bezdrátový internet zdarma. Jde o novou fillozofii každý občan má právo na př́istup k informacím zdarma. ${ }^{7}$

Veřejná sí byla spuštěná v březnu roku 2005 a je primárně určená k vyhledávání na webových stránkách a k emailové korespondenci. Současně může být na sí připojeno až dva tisíce uživatelů. Počet zájemců však není omezen, pokud by se chtělo připojit najednou více občanů, bude připojení pouze pomalejší. Jediným omezením je, že po dvanácti hodinách po přihlášení je spojení přerušeno a zájemce se musí znovu do internetové sítě přihlásit.

Webové stránky Úřadu městské části Prahy 5 jsou v některých částech napojeny na vnitřní informační systém úrúadu a poskytují maximum informací. V rámci předplaceného systému jsou pak dále poskytovány další informace individuálně pro jednotlivé občany. Záměrem připravovaného projektu je realizovat proaktivní informační systém, který by sledoval oběh dokumentů, platby občanů a další skutečnosti související s fungováním úřadu a jeho interakcí s občany. Hlavní přidanou hodnotou systému bude maximální informovanost občanů o průběhu vyřizování jejich žádostí. Systém bude aktivně důležité zprávy zasílat sám, upozorňovat na blížící se termíny atp. Cokoli se bude dít s podáním občanů, jakýkoliv posun ve vyřizování, informace o obdržené či neobdržené platbě, o všem bude občan ihned automaticky informován.

Dle mého názoru je to zajímavý projekt, který má určitě svojí budoucnost. Na druhou stranu zde vzniká otázka, kolik veřejných prostředků bude potřeba na udržování a rozvoje této bezdrátové sítě, aby tato sí byla bezpečná a stabilní. Myslím si, že mnoho lidí dá stále přednost předplacenému internetu od komerčního poskytovatele, kde má jistotu garantovaného rychlejšího připojení a stability sítě.

\section{Závěr}

V současné době můžeme hodnotit úroveň počítačové gramotnosti i jejího využívání ve vztahu k veřejné správě jako relativně vyspělé a zdaleka nezaostáváme za průměrem Evropské unie. Občané stále více nalézají výhody e-govermentu a stále více je také využívají. Nicméně dle mého názoru ještě existují rezervy které by státní správa měla vyplnit aby se ještě více zvýšil zájem o elektronickou komunikaci občanů s orgány státní správy. Jedná se např́iklad o jednodušší získání elektronického podpisu, bud' zcela bezplatně nebo za symbolický poplatek. Předpokládám, že by to motivovalo i ty občany kteří tak často nejednají $\mathrm{s}$ úřady $\mathrm{k}$ upřednostnění elektronické komunikace před tou klasickou.

Je nutné však zmínit, že je nutné disponovat také alternativní komunikací. I když počítačová gramotnost je v dnešní době na vysoké úrovni, je nutné si uvědomit, že existuje také početná skupina těch kteří s informační technikou, nemůžou nebo neumějí pracovat. Jedná se především o osoby $\mathrm{v}$ pokročilém věku, kteří nezvládly a ani snad nemohly

7 STRÁNSKÝ, M. Projekty. Egovernment-elektronizace veřejné správy. 2006, Ročenka, s. 18. 
zvládnout rychlý informačně-technologický pokrok, především v posledních 10-15 letech, nebo osoby různým způsobem handicapované.

Tudíž by se neměl zcela potlačovat ten klasický způsob úřadování, ale možná by se mohl zaměřit úpravami právě na ty občany jež jsou handicapováni tím, že nemohou využívat informační technologie. Jistě by to přispělo k zefektivnění výkonu orgánů státní správy $\mathrm{k}$ jejich spokojenosti z jednoduššího úřadování a především ke spokojenosti občanů.

\section{Literatura}

[1] MATES, P. - SMEJKAL, V. E-government v českém právu. 1. vyd. Praha: Linde, 2006.

[2] ISBN: 80-7201-614-8.

[3] OLŠOVÁ. P. - POŠTA. V. Management v obecní samosprávě. Veřejná správa. 2006,

[4] č. 49. ISSN: 1213-6581.

[5] STRÁNSKÝ, M. Projekty. Egovernment - elektronizace veřejné správy. 2006, Ročenka. ISSN: Bez.

[6] Webové stránky Českého statistického úřadu. [online]. [cit. 2007-03-11].

[7] URL: <http://www.czso.cz/>

[8] Webové stránky Městské části Praha 6. [online]. [cit. 2006-12-15].

[9] URL: <http://www.praha6.cz/> 